\title{
Economic Analysis of Melia dubia Cav. Drupe Pulp as New Alternate Feed for Small Ruminants
}

\author{
M.L. Sukhadiya', N.S. Thakur ${ }^{1 *}$, K.K. Tyagi', V.B. Kharadi', V.R. Patel' and R.P. Gunaga' \\ Department of Silviculture and Agroforestry, College of Forestry, ${ }^{1}$ Vanbandhu College of Veterinary Sciences and Animal \\ Husbandry, Navsari Agricultural University, Navsari -396 450, India \\ ${ }^{2}$ Department of Animal Genetics and Breeding, College of Veterinary Sciences, Sardar Vallabhbhai Patel University of \\ Agriculture and Technology, Meerut-250 110, India \\ *Email: drnsthakur74@gmail.com
}

\begin{abstract}
An experiment was conducted to evaluate the effect of replacing basal diet of goat kids with $20 \%$ and $40 \%$ of Melia dubia Cav. drupe dry pulp to ascertain its effect on body weight, dry matter intake $\left(\mathrm{g} \mathrm{day}^{-1}\right)$, and growth rate, feed conversion ratio and economics of feeding. Twenty four goat kids (average 121 days old and $6.49 \mathrm{~kg}$ live weight) were assigned randomly to $0 \%, 20 \%$, or $40 \%$ M. dubia dry pulp diets (8 kids diet ${ }^{-1}$ ). The study lasted for 90 days. Total mixed rations (TMRs) replaced by M. dubia drupe pulp (BF; Basal feed, $20 \%$ and $40 \%$ M. dubia drupe pulp) did not have any significant effect on body weight, dry matter intake, growth rate and feed conversion ratio by the kids of all groups. Inclusion of $M$. dubia drupe pulp in different TMRs of kids reduced the cost of feeding. Replacement up to $40 \%$ of normal ration with $M$. dubia drupe pulp was most economical. The investigation divulged that feeding is economically beneficial without any difference in growth performance and hence $M$. dubia drupe dry pulp could be a good alternative feed source.
\end{abstract}

Keywords: Melia dubia, Pulp, Feed, Goat kids, Alternate feed, Small ruminants

Agro-industrial by-products and/or alternate feeds may be economically advantageous in reducing feeding costs and can play an important role in feeding of sheep and goats. These include industrial by-products, agro-by-products, horticulture and vegetable wastes, local grasses, tree leaves, tree pods and tree fruit pulps, weeds and other nonconventional feed resources (Andrade-Montemayor et al 2011, Anon. 2012, Obeidat and Shdaifat 2013, Sirohi et al 2017). The interest in search for alternative/additional food and feed ingredients is of paramount importance mainly because of the global demand for grains which has exceeded the production and stiff competition between man and the livestock industry for existing food and feed material (McCalla 2009). Numerous tree species have been evaluated for their leaf fodder or pod feed quality and their effect on livestock and are advocated to reduce cost of feed by replacing the concentrates (Gunasekaran et al 2014, Gebeyew et al 2015, Navale et al 2017, Sirohi et al 2017). Apart from tree leaves and twigs, pods and fruits also being looked as alternate energy rich feed sources for small ruminants and cattle. However, a meager research has been done on fruit pulp of trees for nutritive value and their potential to be utilized as top feeds. Moreover, the use of alternative feed resources which are adaptive to long dry seasons is important for livestock production in arid areas globally (Gusha et al 2015).

There are a number of lesser-known and under-utilized plants that adapted to local, harsh conditions and have tremendous potential as livestock feed. Melia dubia Cav. is one such species, drupes of which could be utilized as top feed. It originates from the Meliaceae family. The species is indigenous to Western Ghats region in India, it is found in Bangladesh, Myanmar, Thailand, Mexico, Sri Lanka, Malaysia, Java, China, America, Philippines and Australia (Thakur et al 2018). It is valued for its high-quality termite and fungus resistant timber, used for furniture, agricultural implements and house construction, as alternative pulp wood species, fuel wood and leaf used as a fodder (Parthiban et al 2009). M. dubia is being planted under industrial agroforestry models and is reported to be a amenable agroforestry ideotype (Thakur et al 2018, Bhusara et al 2018) without any allelopathic effect on under-storey crops (Kumar et al 2017, Parmar et al 2018). It's fruit pulp possess many beneficial biological activities (Susheela et al. 2008, Sukumaram and Raj 2010). Studies suggest that the apart from possible top feed source the drupe pulp could be a good supplement for various ailments in small ruminants and livestock. While collecting the fruits for seed extraction for commercial seedling production, we observed that deer, goats and cattle browse fallen drupe of $M$. dubia from naturally growing trees in the northern Western Ghats parts in Gujarat, India. After having insight in to the literature no scientific report was encountered regarding feeding studies (either on small ruminants or livestock) of dupe pulp of this species. Hence, 
we took this study to evaluate the effect of feeding drupe pulp on growing kids of goat to find out possibilities of it as economic alternative feed resource during lean period..

\section{MATERIAL AND METHODS}

The present investigation was carried out in Livestock Research Station, Vanbandhu College of Veterinary Science and Animal Husbandry, Navsari Agricultural University (NAU), Navsari, in 2018. Twenty four goat kids of average 121 days old and $6.49 \mathrm{~kg}$ live weight were selected. These kids were distributed for three treatments (representing male and female in each treatment). The kids allotted to each treatment were statistically tested as per CRD design and were found statistically at par in age and body weight within three groups.

Three treatments were arranged in a Complete Randomized Design (CRD) with 8 repetitions. The feeding treatments were according to Indian Council of Agricultural Research, New Delhi, India (ICAR, 1998) feeding standard. Treatments were Control (Basal feed; FB), MDDP20replacement of basal feed (Sumul dan- pelleted compound cattle feed manufactured in cattle feed factory of Sumul Cooperative Dairy at Chalthan, Surat Gujarat, India by M. dubia drupe pulp @ 20\%) and MDDP40-replacement of basal feed with M. dubia drupe pulp @ 40\%. Other fodders fed to experimental kids are given in Table 1 and 2 . The feeding period was of 105 days. The first 15 days of the experiment were considered as preliminary period to provide adaptation time to kids for new ration. Mature fresh $M$. dubia drupes were collected from naturally growing trees in Southern Gujarat region, falling in northern Western Ghats of India. Drupes were de-pulped manually and shade dried up to constant weight. Course grounded dry pulp was stored properly. For daily feeding pulp was weighed according to feeding schedule and individually offered to kids of each treatment/group (described later) and after feeding left over was weighed. At the time of feeding of experimental feed kids were shifted in cages individually.

Dry matter intake (DMI g day ${ }^{-1}$ ): The feeds and fodders as per the feeding schedule were weighed before feeding and offered separately to the experimental kids. Daily refused dry fodder of each kid was collected. The DMI Kg/100Kg body weight (BW) was calculated by considering body weight of animals during respective observation. The pooled observations pertaining to DMI were worked out by averaging all fortnight observations.

Body weight (BW) and growth rate: The animals were weighed at fortnight intervals, in the morning before feeding on Weigh Bridge. Fortnightly average daily gain (ADG) was calculated for all experimental kids by working out the difference of particular fortnight observation with previous observation of body weight divided by number of days between these two observations. Likewise the pooled ADG was calculated by working out the differences in body weight from first and last observation divided by number of days between first and last observation. The raw data of ADG (fortnightly and pooled) were subjected to statistical analysis.

Feed conversion ratio (FCR): FCR was calculated the end of the experiment as per procedure described by Mamta and Sharma (2008) using the formula, FCR=Feed consumed $(\mathrm{kg}) / \mathrm{Gain}$ in live weight.

Economics of feeding: All the day to day records regarding fodders, feeds and supplements supplied to experimental kids were maintained. However, the total quantity of feed ingredients for all individual experimental kids was worked out by considering feed intake/day multiplied by duration of experiment (90 days). The price of farm grown green and dry fodder fixed by Directorate of Research, Navsari Agricultural University, Navsari, Gujarat, India, was used to work out the feed cost. The actual purchase price for Sumul dan from the source was used to calculate the feed cost. The cost of feed ingredients consumed during experimental period was worked out by multiplying it with unit price of particular ingredients (Table 4). Thus, the total cost of ration for whole experimental period was calculated for every kid.

Statistical analysis: All respective observations pertaining feeding experiment were analyzed as per standard statistical procedure using Complete Randomized Design (CRD) as experimental design described by Snedecor and Cochran

Table 1. Proximate composition and mineral matter of tree fodder fed ad libitum to experiment kids during study period

\begin{tabular}{|c|c|c|c|c|c|c|c|}
\hline Tree Species & $\mathrm{CP}$ & EE & $\mathrm{CF}$ & NFE & TA & $P$ & $\mathrm{Ca}$ \\
\hline Azadirachta indica & 17.04 & 2.74 & 29.41 & 46.27 & 8.44 & 0.22 & 1.90 \\
\hline Leucaena leucophala & 23.33 & 1.92 & 12.83 & 55.77 & 6.15 & 0.30 & 1.90 \\
\hline Ziziphus mauritiana & 13.10 & 3.90 & 40.27 & 59.81 & 6.70 & 0.21 & 1.20 \\
\hline Hardwickia binata & 10.80 & 3.80 & 27.5 & 47.3 & 10.50 & 0.16 & 2.86 \\
\hline Pithecellobium dulce & 20.20 & 7.20 & 24.2 & 38.10 & 10.30 & 0.35 & 0.96 \\
\hline Samanea saman & 24.70 & 5.90 & 29.2 & 35.00 & 5.20 & 0.26 & 1.28 \\
\hline
\end{tabular}

Source: Gaikwad et al (2017); https://www.feedipedia.org/content/feeds?category=13594, accessed on 02/07/2018

$\mathrm{CP}=$ Crude protein; $\mathrm{EE}=$ Ether extract; $\mathrm{CF}=$ Crude fibre; NFE=Nitrogen free extract $\mathrm{TA}=$ Total ash; $\mathrm{P}=\mathrm{Phosphorous;} \mathrm{Ca=Calcium}$ 
(1980). The means in different treatments were tested for statistical significance using Duncan's multiple range tests with significance difference of $P \leq 0.001$.

\section{RESULTS AND DISCUSSION}

Effect of feeding of $\boldsymbol{M}$. dubia drupe pulp on goat kids: The findings of investigation evinced that, body weight (BW kg kid $\left.{ }^{1}\right)$, dry matter intake (DMI g day ${ }^{-1}$ ), growth rate (GR g day ${ }^{-1}$ ) and feed conversion ratio (FCR) of Surati goat kids and dry matter intake did not vary significantly $(P \leq 0.001)$ among groups either fed entirely on basal feed (BF group) or $20 \%$ (MDDP20 group) or 40\% (MDDP40 group) replacement with M. dubia drupe pulp throughout the feeding period (Table 3 ) after 15 (initial) and 90 days (final) of feeding.

Sirohi et al (2017) replaced standard concentrate mixture with Prosopis juliflora pods and found that average daily dry matter intake (DMI)/100 kg body weight did not differ among the groups. They also reported that, goats were not adversely affected in terms of growth performance. Similarly, Obeidat et al (2008) reported that final body weight, average daily weight gain (ADG) and FCR in Awassi male lambs were not affected when $P$. juliflora pods (PJP) were included at rates of 0,10 and $20 \%$ (replacing barely grains) in lamb diets. Similarly, PJP diets offered ad libitum to replace the barley grain, fed to nursing Awassi ewes and their lambs, did not showed differences $(P>0.05)$ in dry matter (DM), organic matter (OM), crude protein (CP), and metabolizable energy (ME) intake among groups (Obeidatand Shdaifat 2013). Kushwaha and Rai (2011) fed babul pods (Acacia nilotica) to crossbred (Alpine $\times$ Beetal) lactating goats, and concluded that feeding of babul pods to the extent of $16.5 \%$ in TMR equivalent to $3 \%$ tannin in diet could be safely incorporated in the diet of lactating goats without affecting their performance. In present study also there was no effect of feeding M. dubia drupe pulp on growth rate of Surati goat kids due to inclusion of dried pulp up to $40 \%$. Ratan and Sawal (2005) found that grounded siris (Albizia lebbeck) pod incorporated in feeding diet of rams can be moderate source of protein and energy without adversely affecting live weights and wool production of sheep.

Similar to present finding, Kaur et al (2016) supplemented wheat straw with either conventional concentrate mixture (control) or $40 \% \mathrm{KMW}$ (kinnow mandarin (Citrus nobilis Lour $\mathrm{x}$ Citrus deliciosa Tenora) waste $(\mathrm{KMW})$ ) containing concentrate mixture (Treatment) in diet of local goats (age= 8-10 months; $B W=23.00 \mathrm{~kg}$ ). The mean body weights of the animals were similar throughout the feeding trial irrespective of the diet or period indicating that nutrient supply from KMW was sufficient for maintaining the body weight of the animals. They concluded that KMW could be incorporated up to $40 \%$ level in the concentrate mixture without any effect on intake, nutrient digestibility and

Table 2. Composition (\%) of concentrate, green fodder, dry fodder and drupe pulp of $M$. dubia offered to experimental kids

\begin{tabular}{|c|c|c|c|c|}
\hline Attributes & Concentrate $^{*}$ & Green fodder** & Dry fodder* & M. dubia drupe pulp ${ }^{\star \star}$ \\
\hline Dry matter & 90.05 & 25.00 & 90.00 & 29.95 \\
\hline Organic matter & 93.20 & 98.20 & 89.5 & 93.66 \\
\hline Crude protein & 19.60 & 2.20 & 6.00 & 7.63 \\
\hline Crude fibre & 11.20 & 8.00 & 39.00 & 8.31 \\
\hline Ether extract & 2.80 & 0.80 & 1.00 & 5.11 \\
\hline Total ash & 6.80 & 1.80 & 10.5 & 6.34 \\
\hline NFE & 59.60 & 12.20 & 43.50 & 72.60 \\
\hline
\end{tabular}

*Specifications given on Sumul Dan packaging, Sukhadiya (2018), **Sukhadiya et al (2021)

Table 3. Initial and final (After 90 days) body weight (BW), dry matter intake (DMI), growth rate (GR) and feed conversion ratio (FCR) of Surati goat kids fed on different total mixed rations (TMRs) replaced (basal feed Sumul Dan) with M. dubia drupe dry pulp

\begin{tabular}{|c|c|c|c|c|c|c|c|c|}
\hline \multirow[t]{2}{*}{ Feeding treatments } & \multicolumn{2}{|c|}{ Body weight (BW kg/kid) } & \multicolumn{2}{|c|}{ Dry matter intake (DMI g/day) } & \multicolumn{2}{|c|}{ Growth rate (GR g/day) } & \multicolumn{2}{|c|}{ Feed conversion ratio (FCR } \\
\hline & Initial* & Final $^{* *}$ & Initial* $^{*}$ & Final $^{* *}$ & Initial* $^{*}$ & Final $^{* *}$ & Initial* $^{*}$ & Final $^{\star *}$ \\
\hline $\mathrm{BF}$ & $7.01^{\mathrm{a}}$ & $10.13^{\mathrm{a}}$ & $333.098^{\mathrm{a}}$ & $375.63^{\mathrm{a}}$ & $35.83^{\mathrm{a}}$ & $65.00^{\mathrm{a}}$ & $20.01^{a}$ & $8.23^{\mathrm{a}}$ \\
\hline MDDP20 & $7.27^{\mathrm{a}}$ & $10.67^{\mathrm{a}}$ & $334.205^{\mathrm{a}}$ & $377.47^{\mathrm{a}}$ & $47.50^{\mathrm{a}}$ & $57.25^{\mathrm{a}}$ & $9.49^{\mathrm{a}}$ & $8.13^{\mathrm{a}}$ \\
\hline MDDP40 & $7.20^{\mathrm{a}}$ & $10.58^{\mathrm{a}}$ & $334.161^{\mathrm{a}}$ & $376.29^{a}$ & $39.17^{\mathrm{a}}$ & $83.83^{\mathrm{a}}$ & $10.33^{\mathrm{a}}$ & $6.24^{\mathrm{a}}$ \\
\hline $\mathrm{SE}(\mathrm{m})$ & 0.47 & 0.78 & 2.46 & 2.01 & 8.93 & 16.41 & 4.29 & 1.32 \\
\hline
\end{tabular}

BF-Basal feed; MDDP20 $=20 \%$ basal feed replaced by M. dubia drupe pulp; MDDP40=40\% basal feed replaced by $M$. dubia drupe pulp; Same superscript letter in vertical columns denotes non-significant difference according to Duncan's multiple range test (P $\leq 0.001) ;{ }^{*} A f t e r ~ 15$ and ${ }^{* *} 90$ days of feeding 
nitrogen balance. In present study, M. dubia pulp up to $40 \%$ did not showed any negative effect on growth performance of Kids. Vijay et al (2016) fed male crossbred (Black Bengal $x$ Beetal) kids wheat bran of control ration replaced with tamarind seed meal and found that daily DM intake of kids, body weight and average daily body weight gain between groups did not varied significantly. The results indicated that there was no adverse effect of replacement of wheat bran with tamarind seed meal in the ration of kids.

Economics of total mixed rations (TMRs): The study evinced that the cost (Table 4) of feeding was reduced due to inclusion of $M$. dubia drupe pulp in different TMRs of goat kids. $20 \%$ replacement of basal feed with $M$. dubia drupe pulp reduced total cost of TMR to Rs. 492.56 and $40 \%$ replacement reduced the feed cost to Rs. 1012.33/group (8 kids). Hence, the investigation suggests that feeding small ruminants could be economically beneficial without any difference in growth performance.

The economics of feeding small ruminants with industrial by-products, agro-by-products, horticulture and vegetable wastes, tree pods and tree fruit pulps, weeds and other non-conventional feed resources have been found economically beneficial when included in feed replacing the costlier concentrates without any effect on growth performance, production (meat, milk, wool etc.) in small ruminants and cattle. Studies on inclusion of mixed grass hay, milled and whole Acacia tortilis pods of pastoral goats in the arid rangelands (Lengarite et al 2014); feeding fattening Awassi lambs with diets containing PJP $200 \mathrm{~g} \mathrm{~kg}^{-1}$ of diet (Obeidat et al 2008) and PJP as a feed ingredient for nursing awassi ewes (Obeidat and Shdaifat 2013) have been reported to potentially reduce the cost of feed without compromising with growth and milk production.

Fifty per cent replacement of concentrate mixture similar to that of the standard concentrate mixture of PJPO (no Prosopis juliflora pods) with crushed and entire PJP have been found to make diets economical by Rs. 471.50 and 521.50/quintal basis in PJPG and PJPE, respectively (Sirohi et al 2017). Vijay et al (2016) also reported that among three diets i.e. $T_{1}$ (concentrate feed without tamarind seed meal), $T_{2}$ and $T_{3}$ (wheat bran in concentrate feed replaced with a tamarind seed meal at the rates of $1 / 3^{\text {rd }}$ and $2 / 3^{\text {rd }}(\mathrm{w} / \mathrm{w})$ the cost of concentrate mixture per quintal for $T_{1}$ (Rs.1540.00) was maximum followed by $T_{2}$ (Rs. 1529.00) and $T_{3}$ (Rs. 1515.00) and the cost of feed per kg live weight gain remained non-significant among three groups. They concluded that replacement of wheat bran with tamarind seed meal reduced the cost of concentrate feed. Albizia lebbeck pods have been found as a cheaper feed in the arid tropics and can be incorporated as moderate source of

Table 4. Cost and economics of feeding (up to 90 days) Surati goat kids fed on basal feed, and 20 and 40 per cent basal feed replaced with $M$. dubia drupe pulp

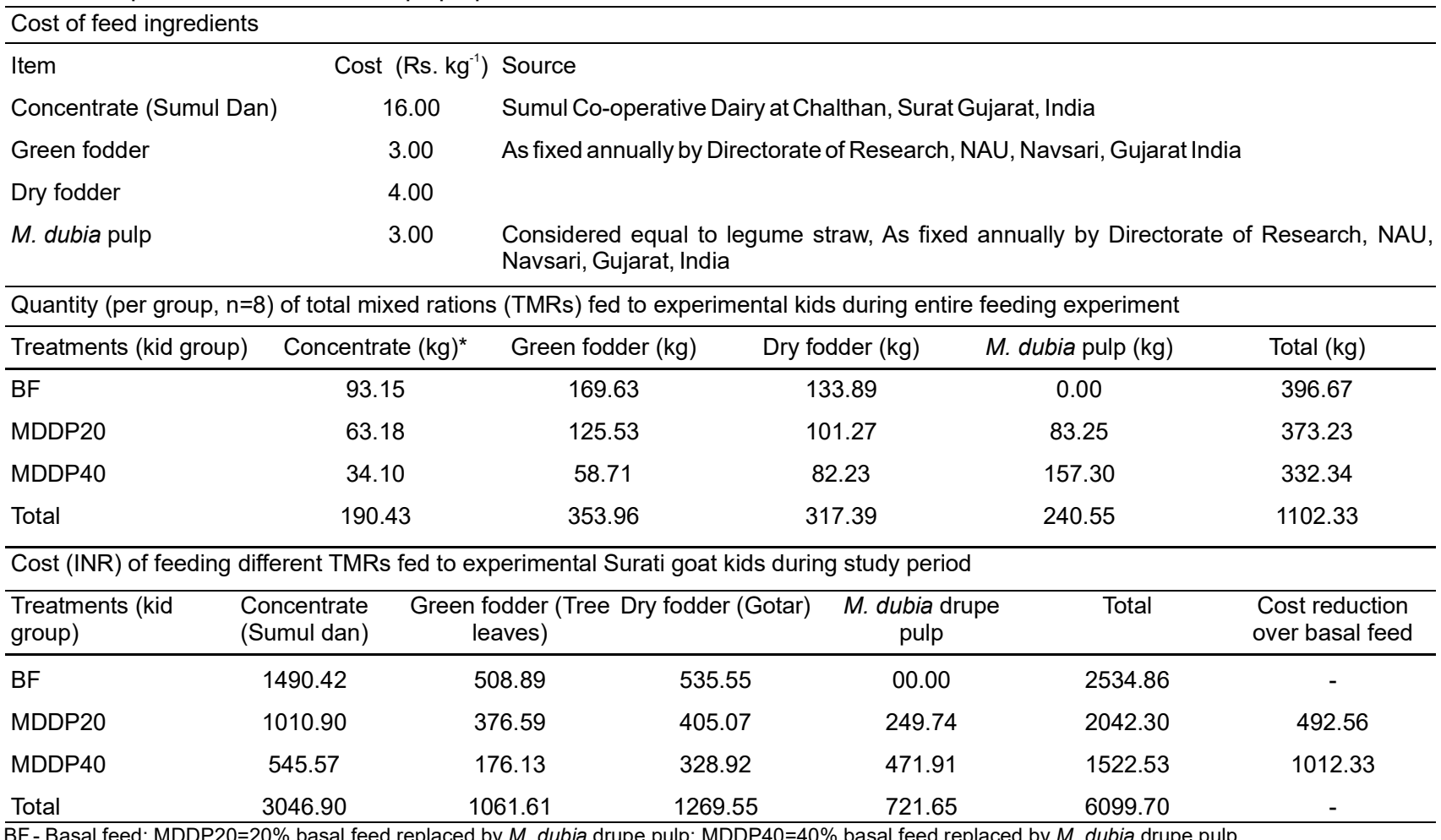

BF - Basal feed; MDDP20 $=20 \%$ basal feed replaced by M. dubia drupe pulp; MDDP40 $=40 \%$ basal feed replaced by $M$. dubia drupe pulp 
protein and energy, substituting up to $40 \%$ in the concentrate supplements without adversely affecting live weights and wool production of sheep (Ratan and Sawal 2005). Mlambo et al (2002) suggested that Dichrostachys cinerea pods can be used by smallholder farmers in place of expensive commercial products, with only inputs required are milling of the pods and storage. These investigations indicate that there are alternative unexplored feed sources which could as good as costlier concentrates. Similarly, M. dubia pulp could be a good energy rich cheap alternative feed supplement for goats in semiarid regions rangelands considering its acceptable nutritional characteristics. It can alleviate nutritional constraints in the dry season.

\section{CONCLUSION}

The results showed that $M$. dubia drupe dry pulp has a good nutrient content indicating the possibility of using it at up to $40 \%$ in goat kids diets to replace basal feed without any negative effect on growth performance. Further, inclusion of M. dubia drupe pulp in different TMRs of Surati goat kids reduced the cost of feeding. The $M$. dubia drupe is a good alternative/agro-industry by-product (pulp extracted from drupes to raise seedlings) as a feed source for small ruminants.

\section{ACKNOWLEDGEMENT}

Authors are thankful to Dr. B. N. Patel, The then Dean, ASPEE College of Horticulture and Forestry, and Dr. N. H. Kelawala, the then Dean, Vanbandhu College of Veterinary Sciences and Animal Husbandry, NAU, Navsari, Gujarat, India, for providing necessary support to conduct feeding experiment on Goat kids at Livestock Research Station.

\section{REFERENCES}

Andrade-Montemayor HM, Cordova-Torres AV, Garcia-Gasca T and Kawas JR 2011. Alternative foods for small ruminants in semiarid zones, the case of mesquite (Prosopis laevigata spp.) and Nopal (Opuntia spp.). Small Ruminant Research 98(1-3): 83-92.

Anonymous 2012. Nutritive value of commonly available feeds and fodders in India. Animal Nutrition Group. National Dairy Development Board, Anand, India. pp. 112.

Bhusara JB, Dobriyal MJ, Thakur NS, Sondarva RL and Prajapati DH 2018. Growth and yield performance of green gram under Melia composita plantations. Journal of Pharmacognosy and Phytochemistry 7(3): 1490-1494.

Chandra J and Mali MC 2014. Nutritional evaluation of top five fodder tree leaves of mimosaceae family of arid region of Rajasthan. International Journal of Innovative Research and Review 2(1): 14-16.

Gaikwad US, Pawar AB and Kadlag AD 2017. Nutritional status of fodder tree leaves and shrubs of scarcity zone of Maharashta. Advances in Life Sciences 7(1): 11-14.

Gebeyew K, Beriso K, Mohamed A, Silassie G, Melaku S and Worku A 2015. Review on the nutritive value of some selected Acacia species for livestock production in dryland areas. Journal of
Advance Dairy Research 3(2): 139.

Gunasekaran S, Viswanathan K and Bandeswaran C 2014. Selectivity and palatability of tree fodders in sheep and goat fed by cafeteria method. International Journal of Science Environment and Technology 3(5): 1767-1771.

Gusha J, Halimani TE, Katsande S and Zvinorova PI 2015. The effect of Opuntia ficusindica and forage legumes based diets on goats productivity in smallholder sector in Zimbabwe. Small Ruminant Research 125: 21-25.

ICAR (Indian Council of Agricultural Research) 1998. Nutrient Requirements of Domestic Animals. Indian Council of Agricultural Research, New Delhi, India. 210 pp.

ICAR (Indian Council of Agricultural Research) 2001. Annual report 2000-01. National Centre for Economics and Policy Research. ICAR, New Delhi. 24-25 pp.

Kaur Ravlin, Rastogi A, Sharma RK and Singh M 2016. Evaluation of kinnow mandarin fruit waste in rations of goats. Indian Journal of Animal Nutrition 33(4): 416-420.

Kumar D, Thakur NS and Gunaga RP 2017. Effects of leaf aqueous extract and leaf litter of Melia composita Willd. on black gram [Vigna mungo (L) Hepper]. Allelopathy Journal 41(1): 127-140.

Kushwaha R and Rai SN 2011. Effect of feeding Acacia nilotica pods on feed intake, nutrient utilization and balances of $\mathrm{N}, \mathrm{Ca}$, and $\mathrm{P}$ in lactating goats. Indian Journal of Animal Nutrition 28(3): 309315.

Lengarite MI, Getachew G, Akudabweni L and Hoag D 2014. Supplementary feeding of lactating goats with processed and unprocessed Acacia tortilis pods and local grass in the dry season in northern Kenya. Agricultural Science Research Journal 4(3): 63-71.

Mamta and Sharma P 2008. Effect of probiotics on body weight gain and feed conversion ratio in goat kids. Haryana Veterinarian 47: 39-40.

McCalla AF 2009. World food prices: Causes and consequences. Canadian Journal of Agricultural Economics 57: 23-34.

Mlambo V, Mould FL, Owen E, Smith T, Mueller-Harvey I and Sikosana, JLN 2002. Dichrostachyscinerea pods as a protein supplement for goats fed on hay based diets. Goat keepers cluster reports: ProjectR7351.

Navale M, Bhardwaj DR and Bishist R 2017. Seasonal variation in nutritional quality of Pittosporum floribundum in mid hills of Himachal Pradesh. Indian Journal of Animal Nutrition 34(2): 233-237.

Obeidat BS, Abdullah AY and Al-Lataifeh FA 2008. The effect of partial replacement of barley grains by Prosopis juliflorapods on growth performance, nutrient intake, digestibility, and carcass characteristics of Awassi lambs fed finishing diets. Animal Feed Science and Technology 146: 42-54.

Obeidat BS and Shdaifat MM 2013. Partial substitution of barley grain with Prosopis juliflora pods in lactating Awassi ewe's diets: Effect on intake, digestibility, and nursing performance. Small Ruminant Research 111: 50-55.

Parmar AG, Thakur NS and Gunaga RP 2019.Melia dubia Cav leaf litter allelochemicals have ephemeral allelopathic proclivity. Agroforestry Systems 93(4): 1347-1360.

Parthiban KT, Bharathi AK, Seenivasan R, Kamala K and Rao MG 2009. Integrating Melia dubia in agroforestry farms as an alternate pulpwood species. APANews 34: 3-4.

Ratan R and Sawal RK 2005. Influence of siris (Albizia lebbeck) pods supplementation in sheep production. Indian Journal of Small Ruminants 11(1): 43-47.

Sirohi AS, Mathur BK, Misra AK and Tewari JC 2017. Effect of feeding crushed and entire dried Prosopis juliflora pods on feed intake, growth and reproductive performance of arid goats. Indian Journal of Animal Science 87(2): 238-240.

Snedecor GW and Cochran WG 1980. Statistical methods, $7^{\text {th }}$ Edition, lowa State University Press, Ames. USA. 292pp. 
Sukhadiya ML 2018. Evaluation of nutritive value of drupe pulp of Melia dubia cav. and its feeding effect on surati goat (Capra aegagrus hircus L.) kids. M.Sc. Thesis, Navsari Agricultural University, Navsari, Gujarat, India, 89pp.

Sukhadiya ML, Thakur NS, Patel VR, Gunaga RP, Kharadi, VB, Tyagi KK and Singh S 2021. Provenance variations in proximate principles, mineral matter, total phenols and phytochemicals of Melia dubia drupes: an unexplored alternate livestock feed stock. Journal of Forestry Research 32(1): 119-131.

Sukumaram S and Raj ADS 2010. Medicinal plants of sacred groves in Kanyakumari district Southern Western Ghats. Indian Journal of Traditional Knowledge 9(2): 294-299.

Received 11 October, 2021; Accepted 28 December, 2021
Susheela T, Balaravi P, Theophilus J, Reddy NT and Reddy PUM 2008. Evaluation of hypo-glycaemic and anti-diabetic effect of Melia dubia Cav. fruits in Mice. Current Science 94: 11911195.

Thakur NS, Jilariya DJ, Gunaga RP and Singh S 2018. Positive allelospoly of Melia dubia Cav spatial geometry improve quantitative and qualitative attributes of Aloe vera L. Industrial Crops and Products 119: 162-171.

Vijay L, Sinha AK, Sinha SK and Swati Shivani 2016. Effect of feeding tamarind (Tamarindus indica) seed meal on nutrient intake, its utilization and growth in crossbred kids. Indian Journal of Small Ruminants 22(2): 182-185. 